\title{
Dialogic Reading of a Novel for Children: Effects on Text Comprehension ${ }^{1}$
}

\author{
Eileen Pfeiffer Flores ${ }^{2}$ \\ Universidade de Brasília, \\ Brasília-DF, Brazil
}

\author{
Laís Fernandes Pires \\ Universidade de Brasília, \\ Brasília-DF, Brazil
}

\author{
Carlos Barbosa Alves de Souza \\ Universidade Federal do Pará, \\ Belém-PA, Brazil
}

\begin{abstract}
Experimental studies have shown positive effects of dialogic reading of picture books (reading aloud interspersed with prompts and feedback for verbalizations by the listener) on the vocabulary and verbal expression of small children. This study assessed the effect of dialogic reading on the comprehension of a children's novel by three children aged 7-8 years, using a single-subject reversal design. In Condition A, the text was read without intervention. In Condition B, reading was interspersed with dialogic interventions based on narrative functions. Comprehension was superior in all measures in Condition $\mathrm{B}$ for the two participants who underwent the B-A-B design, however, not for the participant who underwent the A-B-A design. We discuss possible interactions of dialogic reading with characteristics of text genre and the need for systematic replications with more sessions and reversals of conditions.
\end{abstract}

Keywords: reading, verbal comprehension, children (Brazil)

\section{Leitura Dialógica de um Romance Infanto-Juvenil: Efeitos Sobre a Compreensão Textual}

\begin{abstract}
Resumo: Estudos experimentais têm demonstrado efeitos positivos da leitura dialógica de livros ilustrados (leitura em voz alta intercalada com prompts e feedback para verbalizações por parte do ouvinte) sobre o vocabulário e a expressão verbal de crianças pequenas. Este estudo verificou o efeito da leitura dialógica sobre a compreensão textual de um romance infanto-juvenil por três crianças de 7-8 anos, utilizando um delineamento de sujeito único. Na Condição A, o texto era lido sem intervenções. Na Condição B, a leitura era intercalada com intervenções dialógicas baseadas nas funções narrativas presentes no texto. As medidas de compreensão mostraram um desempenho superior na Condição B para os dois participantes submetidos ao delineamento B-A-B, mas não para o participante submetido ao delineamento A-B-A. São discutidas possíveis interações da leitura dialógica com características do gênero textual e a necessidade de replicações sistemáticas com um maior número de sessões e reversões das condições.
\end{abstract}

Palavras-chave: leitura, compreensão verbal, crianças (Brasil)

\section{Lectura Dialógica de una Novela Para Niños: Efectos Sobre la Comprensión de Textos}

\begin{abstract}
Resumen: Estudios experimentales han demostrado efectos positivos de la lectura dialógica de libros ilustrados (lectura en voz alta intercalada con indicaciones y feedback para verbalizaciones del oyente) sobre el vocabulario y la expresión verbal de niños pequeños. Este estudio investigó efectos de la lectura dialógica sobre la comprensión de una novela infanto-juvenil por tres niños (7-8 años), usando un diseño de sujeto único. En la condición A, el texto fue leído sin intervención. En la condición B (lectura dialógica), la lectura se intercaló con intervenciones dialógicas preparadas a partir de las funciones narrativas presentes en el texto. Las medidas de comprensión mostraron un desempeño superior en la Condición B para los dos participantes sometidos al diseño B-A-B, pero no para el participante sometido al diseño A-B-A. Son discutidas las posibles interacciones de lectura dialógica con características del género textual y la necesidad de repeticiones sistemáticas con un número mayor de sesiones experimentales y de reversiones de las condiciones.
\end{abstract}

Palabras clave: lectura, comprensión verbal, niños (Brasil)

Various studies directed toward classroom practice rely on the assumption of the positive effects of shared reading (reading aloud by an adult to one or more children) for the development of language skills (e.g., Flynn, 2011; Morrow, 2009). However, systematic studies are needed to verify,

\footnotetext{
1 Acknowledgment: The authors thank Dapheny Day Leandro Feitosa and Raquel Coelho for support during data collection and two anonymous reviewers for their valuable insights.

Support: National Council for Scientific and Technological Development (CNPq).

2 Correspondence address:

Eileen Pfeiffer Flores. Departamento de Processos Psicológicos Básicos. Instituto de Psicologia. Instituto Central de Ciências, Campus Darcy Ribeiro. CEP 70910-900. Brasília-DF, Brazil.

E-mail: eileenpfeiffer@gmail.com
}

firstly, what aspects of language benefit from shared reading and, secondly, what specific forms of shared reading produce these benefits.

Whitehurst and Lonigan (1998, see also Cabell, Justice, Konold, \& McGinty, 2011) offered a typology of the skills related to what they call 'emergent literacy', which consists of the set of skills, knowledge and attitudes necessary for reading and writing. The skills related to emergent literacy were divided into two types by the authors: 'inside-out' skills - knowledge of graphemes, phonological awareness (e.g., recognizing rhymes), and syntactic awareness (e.g., recognizing grammatical errors), - and 'outside-in' skills - semantic and conceptual knowledge (e.g., vocabulary, general knowledge), comprehension of narratives, knowledge of the conventions of the printed word 
(e.g., to know that reading is done top to bottom and left to right) and emergent reading (e.g., when the child pretends to read before being formally literate).

Whitehurst and collaborators (e.g., Whitehurst et al., 1988; Whitehurst et al., 1999) conducted studies in which they tested the relationship between a type of interactive shared reading, which they called dialogic reading, and the emergence of literacy skills. Dialogic reading is characterized as the reading aloud of a text (usually a children's picture book) by an adult to one or more children, during which the adult presents hints or prompts so that the child emits verbalizations regarding the story and the illustrations. The type of questions asked are $w$ - questions ("who, when, where, how, which, and what"), questions that relate aspects of the story to the child's life, vocabulary questions, requests for the child to recall or anticipate parts of the story, requests for naming or describing the book's illustrations, among others. Furthermore, the adult provides feedback for the verbalizations, such as repeating the correct answers, modeling answers, and extending the child's responses.

The first experimental study on the effects of dialogic reading was performed by Whitehurst et al. (1988). Thirty children of preschool age and their caregivers were divided into a control group and an experimental group. The caregivers were informed about the importance of reading aloud and were asked to choose picture books from their personal collections to read during the following weeks. The caregivers in the experimental group participated in two training sessions of dialogic reading techniques and were instructed to put them into practice over the following four weeks when reading to the children. The caregivers in the control group read to their children as they had previously been doing. The caregivers of the experimental group used the dialogic reading techniques at a higher frequency than the control group and the children showed significantly greater gains in standardized vocabulary tests (reading frequency in the two groups did not differ).

Subsequent studies have shown that dialogic reading particularly favors the skills that Whitehurst and Lonigan (1998) called outside-in, such as vocabulary, use of syntactic resources and story grammar (Fontes \& Cardoso-Martins, 2004; Lever \& Sénéchal, 2011; Lonigan, Purpura, Wilson, Walker, \& Clancy-Menchetti, 2013; Valdez-Menchaca \& Whitehurst, 1992; Zevenbergen, Whitehurst, \& Zevenbergen, 2003; for reviews, see Camelo \& Souza, 2009; Vally, 2012). There is also evidence that dialogic reading promotes the development of vocabulary linked to social-cognitive issues, such as attribution to others of feelings, intentions and other mental states (Aram, Fine, \& Ziv, 2013; Rodrigues, Ribeiro, \& Cunha, 2012; Zevenbergen et al., 2003).

In Brazil, Fontes and Cardoso-Martins (2004) investigated the effects of a form of interactive reading similar to dialogic reading, which included discussion about the story before, during, and after shared reading, on the vocabulary and comprehension of 36 children from low-income families, aged 5-6 years. The children in the experimental group participated in 16 sessions of interactive reading of children's stories, in small groups of up to four children, while the children in the control group did not undergo any special treatment. Pre- and post-tests of reading and writing, vocabulary and comprehension skills were carried out. Gains in vocabulary and comprehension were higher for the experimental group, but reading and writing skills were not affected.

The aforementioned experiments used group designs and described results using aggregate values. Such aggregate analyses are especially recommended for largescale studies designed to assess whether certain practices or interventions are, on average, effective with certain populations (Gast, 2010). This was the aim, for example, of Whitehurst et al. (1999), who evaluated the efficacy of the inclusion of dialogic reading in academic prevention and compensation policies. However, as Gast (2010) points out, aggregate values resulting from group designs obscure data of individuals for whom the independent variable has no effect, as well as those for whom the variable has an effect greater than the mean. On the contrary, in singlesubject designs, each participant is repeatedly exposed to various conditions, thus allowing the verification of how the independent variable influences dimensions of the behavior of each individual (for more detailed descriptions of characteristics, advantages and disadvantages of the single-subject designs, see Gast, 2010 and Johnston \& Pennypacker, 2008). In addition, previous studies that evidenced the positive effects of dialogic reading on comprehension were carried out with preschoolers and used adaptations of standarized tests or very short stories (e.g., Fontes \& Cardoso-Martins, 2004; Zevenbergen et al., 2003). It is therefore important to investigate whether shared reading and, specifically, dialogic reading, might have beneficial effects on the comprehension of more complex narratives, such as children's novels.

In summary, the experimental studies related to dialogic reading have, until the present, been predominantly performed in countries other than Brazil, have investigated shared reading of short texts and picture books, and have used group designs. In Brazil, the study by Fontes and Cardoso-Martins (2004) showed positive effects of a form of dialogic reading. However, it was not possible to conclude whether the effect was due to the specific form of reading or to other variables, such as exposure to shared reading or even the presence and attention of the researcher, since the children in the control group were not exposed to any treatment. In their discussion, Fontes and Cardoso-Martins highlight the need for studies in which the control-condition includes non-dialogic reading. Considering these issues, the present study investigated the effects of dialogic reading on textual comprehension of a children's novel, with three Brazilian children aged 7-8 years. 


\section{Method}

\section{Participants}

The study participants were one boy aged eight years (P1) enrolled in the third year of Elementary Education at a private school, and one girl (P2) and one boy (P3), seven and eight years of age, respectively, enrolled in the third year of Elementary Education at a public school. Participant P1 was originally a student at the same school as $\mathrm{P} 2$ and $\mathrm{P} 3$ and was selected when participating in a university-community partnership project (Livros Abertos: Aqui Todos Contam!), having shown, at the time, a strong interest in the novel that was to be used in the study. He was transferred to the private school before data collection was started and his involvement continued at his request and with the consent of his family members. P2 and P3's participations were recommended by the school pedagogical staff, who reported difficulties for both children in the literacy process and in oral and written expression, as observed by classroom teacher. None of the children had previous contact with dialogic reading.

\section{Instruments}

The following instruments and measures were used:

Children's novel. The book Minha mãe é uma Pirata (My Mom the Pirate, French \& King, 2007) was used for shared reading due to (a) predominance of text and continuous narrative (b) its main theme (pirate adventure) which had shown to appeal to the age group of the participants in previous readings in the context of the university-community partnership project previously mentioned. The novel was divided into 12 sections, each suitable to be read in one session. Each section consisted of a complete narrative, with beginning, middle and end, although it was part of the larger narrative. Therefore, at the end of the experiment the child would have read the entire novel. The sessions were recorded using a digital camcorder and a laptop was used (a) to store and reproduce the recordings of the sessions and (b) to record and present the sentences used in the Sentence Game (see description below).

Analysis of narrative functions and development of prompts. With the dual purpose of preparing the prompts that would be used in dialogic reading sessions and assessing comprehension, a criterion was sought that would enable important aspects of the narrative to be captured, taking into account not only the sequence of events in the story, but also descriptions of characters, descriptions of scenes, indications of characters' emotional states or intentions, humoristic functions, among others, which played an important role for narrative comprehension. This aim led to a text analysis based on the notion of "functional text units" proposed by Barthes (1966/2009). A functional text unit or function is defined by the role that it fulfills in relation to the narrative as a whole, not by the formal or thematic characteristics of that specific segment. The functional unit has no defined size, and may even be spread over several points of the narrative. For example, a function of the text used in Session 1 was to denote that one of the characters, the Mother-Pirate, was kind, though illtempered, and one of the parts of the narrative that fulfilled this function was the statement of a character who said that, when Mother-Pirate threw a bad pirate overboard, soon afterwards she threw him a buoy, so he would not drown. Using this concept, the analysis and listing of the narrative functions was carried out for each of the twelve text sections. In order to avoid creating arbitrary or irrelevant functions, the evidence in the text (events in the story, descriptions, character's thoughts, etc.) was sought and listed for each narrative function that was proposed. Analysis was performed by the first two authors or by one of them, with a subsequent review by the other. Once the functions of each section were listed, possible prompts that emphasized each function were prepared. For example, the prompt "What do you think Cecil feels for Snap?" was created to emphasize the text function "To evidence affection between the boy-pirate Cecil and his crocodile Snap".

Analysis of the sequence of events. In order to evaluate the story events cited by the child when retelling the story, the events of the narrative were analyzed and listed for each of the twelve sections of text, in chronological order. For example, a section of the sequence of events of the text used in Session 2 was (a) Cecil wakes up; (b) puts on his pirate clothes; (c) goes to the kitchen; (d) notices the special birthday decorations; (e) Percival Rotten wishes Cecil a happy birthday.

Sentence game. In order to prepare one of the comprehension tasks, which was called the 'Sentence Game', sentences related to the narrative functions were created for each of the twelve text sections. For each narrative function found in the text section, a true sentence and a false sentence were created. For example, one of the narrative functions of the section read in Session 6 was "To evidence the changing attitudes of Big Bernie, from coward and bully to a brave and good friend". For this function the sentences Big Bernie, for the first time, showed courage and helped Cecil to fight (true) and Big Bernie, as always, proved cowardly and did not want to join the fight (false) were created. The sentences prepared for each section were read in random sequence by a volunteer student who did not know the hypotheses of the research and her reading was audio recorded.

Registration sheets. For each section of the text, i.e., for each session, a protocol was prepared for registration of performance during comprehension tasks. The sheet contained a space for session information and checklists that listed and allowed scoring of (a) narrative functions achieved, (b) events cited, and (c) correct responses in the Sentence Game. There was also a column with the prompts planned for that session, for checking and registering prompts actually used.

\section{Procedure}

Data collection. Participant P1 performed all sessions in a room of the psychological care center of the university, which had air conditioning, artificial lighting and partial 
soundproofing. Participants P2 and P3 performed the sessions in their school library, which was artificially and naturally lit and was ventilated by tilting windows, with no soundproofing. During sessions, a sign was posted on the door informing of the ongoing experiment and one of the researchers remained outside to prevent interruptions. The sessions were held during class hours, when the school was relatively quiet. In all cases, the child and the researcher sat side by side at a circular table, which allowed them to interact face-to-face and look at the book together with ease. The video camera was mounted on a tripod and positioned so that it framed the child and researcher and remained on throughout the entire session.

Before starting the experiment, two adaptation sessions were carried out, in which two stories that would not be used in the data collection were told, with the aim of establishing rapport and familiarizing the children with the researchers and with the research situation. The adaptation sessions were followed by 12 experimental sessions, conducted with each child individually, four afternoons a week, during three weeks (P1 began his participation two weeks before the others).

Before each session, the first author studied the section to be read (the entire novel had already been read several times before), rehearsed reading aloud and memorized the planned prompts. Each session lasted between 20 and 30 minutes. Initially, the first author read the section to the child, in accordance with the experimental condition. In condition A (non-dialogic reading), the text was read to the child without prompts or any other dialogue initiated by the researcher. Any questions and spontaneous comments about the text were acknowledged and answered, however, they were not followed by new questions or comments from the researcher, who resumed reading. In condition B (dialogic reading), the reading was interspersed with the prompts planned for that session and responses were followed by feedback. When the child answered according to the narrative function aimed by the prompt, his/her response was confirmed with praise, repetitions or paraphrases. When the answer was partially correct or incomplete, it was followed by new prompts. When the child did not answer, the question was repeated or rephrased. If necessary, the researcher presented a model of the correct response and/or an explanation and asked the child to verbalize what was comprehended. Both the narrative functions and the child's performance guided the researcher's questions and feedback.

Once shared reading was over, the first author left the room, and the second author immediately entered to present three comprehension tasks: (a) Free Retelling (general instructions to retell the story), (b) Directed Retelling (fixed questions about the setting, characters and parts of the story), and (c) Sentence Game (judgment of sentences as true or false in relation to the story). For the Free Retelling task, the participant was instructed to tell the story they had just heard "in the best possible way". If they said they did not remember anything, the researcher insisted that they try to tell whatever they remembered. When the participant indicated having completed the retelling, the researcher asked: "Do you remember anything else?", "Did anything else happen?" or "Do you want to add anything else?". If the reply was negative, the next task was initiated: Directed Retelling, in which the researcher asked: "Where did the story start today?"; "What was happening when the story began?"; "Who were the characters in the story today?"; "What do you think was the most important part of the story today?"; and "What part did you like best?". The Sentence Game took place next, in which the child listened to prerecorded audio phrases and was instructed to judge them by saying "yes" if the sentence was correct, and "no" if it was incorrect. Two examples were given in the first session, to verify if the participant had understood the instructions. The children were also informed that they could ask the researcher to play the phrase again if they felt the need, as many times as necessary.

With P1, who started the experiment two weeks before $\mathrm{P} 2$ and P3, a B-A-B design was used, in order to test (a) whether the effects of dialogic reading were reversible, thus allowing the use of reversal designs, and (b) whether changes in performance on comprehension tasks occurred when the dialogic reading condition was withdrawn and when it was reintroduced. With $\mathrm{P} 2$, the experimental design performed with P1 was replicated. However, conditions were reversed in different sessions, following the logic of a multiple baseline across subjects design. This was done to control the possible effect of specific sections of the narrative on the performance. With participant P3 an A-B-A design was used to assess the effects of the independent variable before the intervention. Reversals were decided by visually examining data, using criterions of stability, within the limitation of the twelve sessions planned.

Data analysis. After each session, the film record was analyzed and the registration sheet was completed with functions achieved and events cited by the participant in the Free Retelling and Directed Retelling tasks, and with the number of correct responses in the Sentence Game. A function was considered achieved when the child narrated the section of the story that fulfilled that function or, in some other manner, included it in the narrative. For example, the function "to show that the character Cecil was very sad" was achieved if the child said that he was crying and unwilling to play or, simply, if the child said he was very sad (among other possibilities).

Comprehension measures were: (a) the total number of functions cited by the child divided by the total number of functions identified in the text $\mathrm{x} 100$ (percentage of functions); (b) the total number of story events cited by the child divided by the total number of events identified in the text $\times 100$ (percentage of events); and (c) the percentage of correct responses in the Sentence Game (percentage of correct responses - used only for participants $\mathrm{P} 2$ and 
P3). Since the Directed Retelling task added little new data to the performance of the participants (with few exceptions, the children repeated what they had already reported in the Free Retelling task), percentage of events and percentage of functions were calculated considering combined performance on both tasks. The data obtained in each session were recorded daily in tables and graphs for the purpose of visual analysis and decisions concerning the next sessions.

After finishing data collection from P1, the first two authors and an undergraduate student, who did not know the aims of the study, independently assessed a random sample of five sessions. Prior to the evaluation, the student read the novel and received an explanation regarding the concepts of narrative functions and narrative events, using examples from other sessions. Agreements (total agreements/agreements + disagreements) in the evaluation of the percentage of functions achieved, events cited, and correct responses in the Sentence Game were calculated. An agreement was considered only if all the reviewers marked that function or event as having been achieved. The agreements between the evaluators ranged between $98 \%$ and $100 \%$.

In order to assess implementation of the dialogic reading condition and its differentiation from the control condition, analysis of the recordings also included verifying which prompts, among those planned for the session, were effectively given by the researcher during shared reading. This confirmed that no prompts were given in the non dialogic condition and that at least one of the prompts planned for each function was always given in the dialogic reading condition.

\section{Ethical Considerations}

This study was approved by the Research Ethics Committee of the Faculdade de Ciênicas da Saúde of the Universidade de Brasília (Protocol No. 089/11).

\section{Results}

Figure 1 presents the percentage of functions (upper graph) and percentage of events (lower graph) cited by P1, per session. Sessions 1-3 were carried out in Condition B (dialogic reading), sessions 4-8 in Condition A (non-dialogic reading) and sessions 9-12 in Condition $\mathrm{B}$ again. Percentage of functions cited was above $85 \%$ in Condition $\mathrm{B}$ and ranged between $40 \%$ and $75 \%$ in Condition A, with the exception of Session 6 (83\%). Upon return to Condition B, percentage of functions achieved was $80 \%$ in the first session, and remained at $100 \%$ in the three final sessions.

The percentage of events cited by $\mathrm{P} 1$ ranged between $80 \%$ and $100 \%$ in the first three sessions (Condition B), between $44 \%$ and $77 \%$ in the five Condition A sessions, and between $77 \%$ and $81 \%$ upon reversal to Condition B. In general, there was a higher percentage of events cited in Condition B. The pattern of results followed those of narrative functions, although less dramatically: there was a decrease in performance in the non-dialogic reading condition (A) and a recovery of performance upon return to the dialogic reading condition (B), and there was more variability in performance during non-dialogic reading.

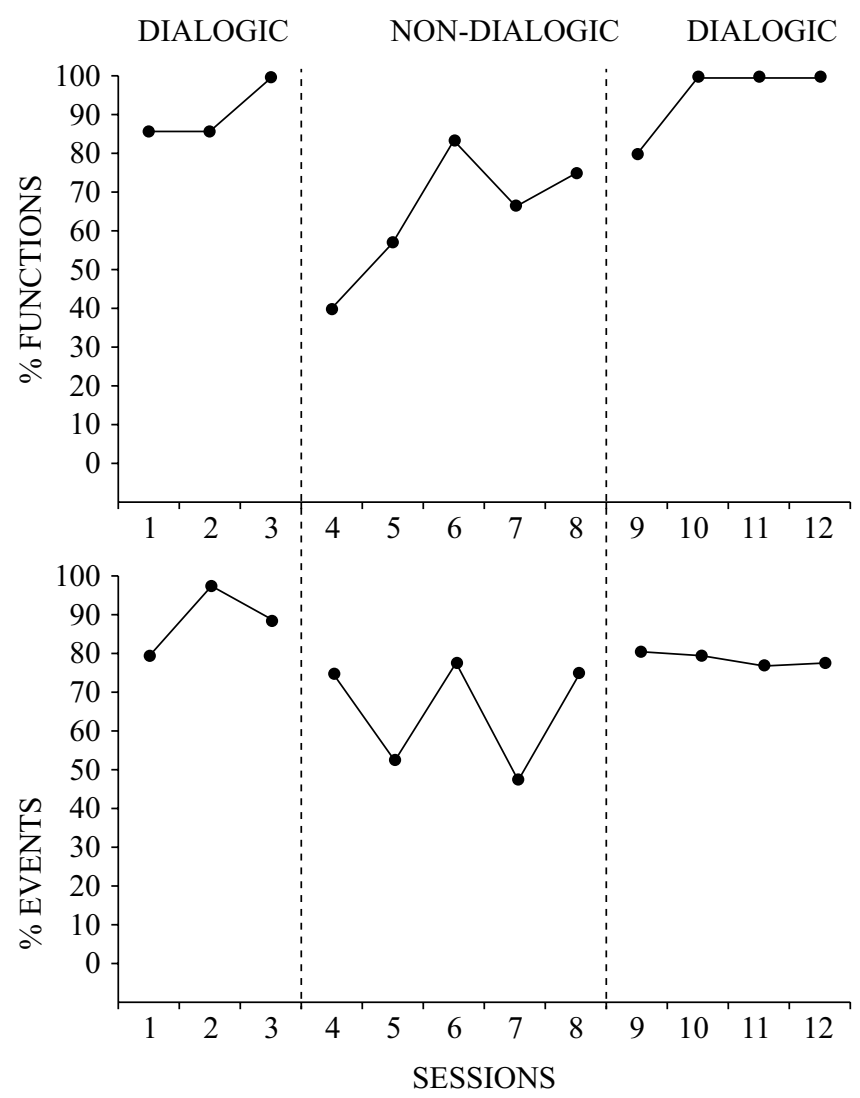

Figure 1. Percentage of narrative functions achieved and events narrated, per session, for participant P1.

Figure 2 presents the percentage of functions achieved (upper graph), events narrated (middle graph), and correct responses in the Sentence Game (lower graph) for P2, per session. Sessions 1-5 were performed in Condition B, Sessions 6-9 in Condition A, and Sessions 10-12 in Condition B. The percentage of functions achieved ranged between $50 \%$ and $71 \%$ during the first exposure to Condition B, between $0 \%$ and $33 \%$ in Condition A and between 33\% and $57 \%$ upon reversal to Condition B. A sharp decrease in the percentage of functions achieved was observed upon transition to non-dialogic reading and there was an increasing trend in the number of functions achieved when dialogic reading was resumed.

The effect of withdrawal of dialogic reading on the events narrated was not as clear in the case of $\mathrm{P} 2$, as there was already a decrease in performance before change of condition. However, in general, performance was lower in Condition A: percentage of events achieved varied between $12.5 \%$ and $66.67 \%$ in the first exposure to Condition B, 
DIALOGIC NON-DIALOGIC DIALOGIC
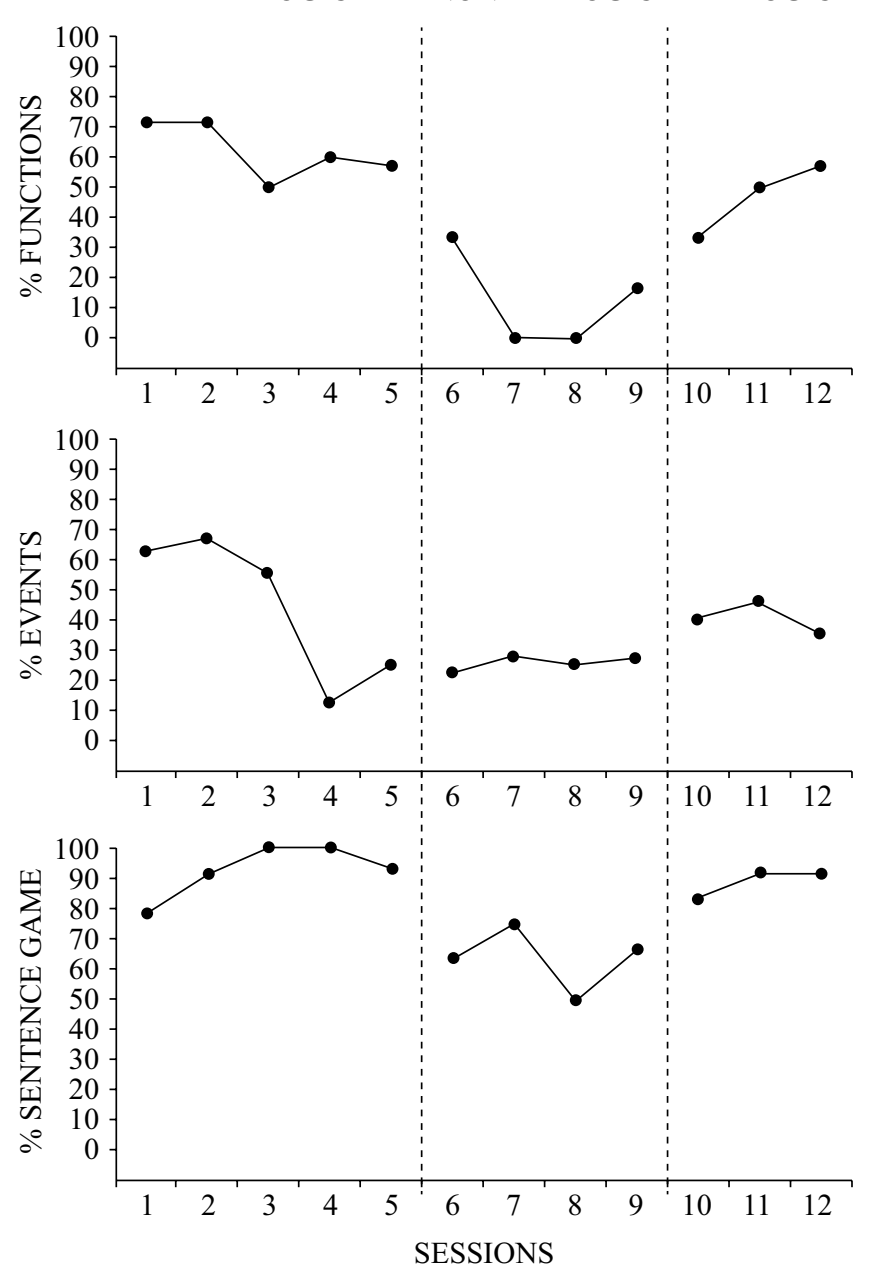

Figure 2. Percentage of functions achieved, events narrated and correct responses in the Sentence Game, per session, for participant P2.

between $22.23 \%$ and $27.78 \%$ in Condition $\mathrm{A}$, and between $35.3 \%$ and $46.15 \%$ upon return to Condition B.

Correct responses in the Sentence Game ranged between $79 \%$ and $100 \%$ in Condition B, between $50 \%$ and $75 \%$ in the four sessions of Condition $\mathrm{A}$ and between $83 \%$ and $92 \%$ in the return to Condition B. In general, P2's performance in the dialogic sessions was higher than performance in the non-dialogic sessions for all the measurements. This data replicates, with lower values, the general data pattern obtained with $\mathrm{P} 1$. When comparing the values of correct responses in the Sentence Game with the functions and events cited, it was also noted that performance in the Sentence Game was higher than performance in the storytelling tasks, in all conditions.

Figure 3 presents percentage of functions achieved (upper graph), events cited (middle graph) and correct responses in the Sentence Game (lower graph) for P3, per session. Sessions 1-5 were performed in Condition A (nondialogic) and Sessions 6-12 in Condition B (dialogic), with a probe in Condition A during Session 11. The number of functions achieved varied between $40 \%$ and $57 \%$ in Condition A, and between $25 \%$ and $67 \%$ in Condition B, with a "U" pattern between session 6 and 10. The return to Condition A probe was included in order to verify whether there would be a decrease in the number of functions achieved, which in fact occurred. However, this result is insufficient to draw conclusions about a systematic relationship between the percentage of functions achieved and the conditions for P3,

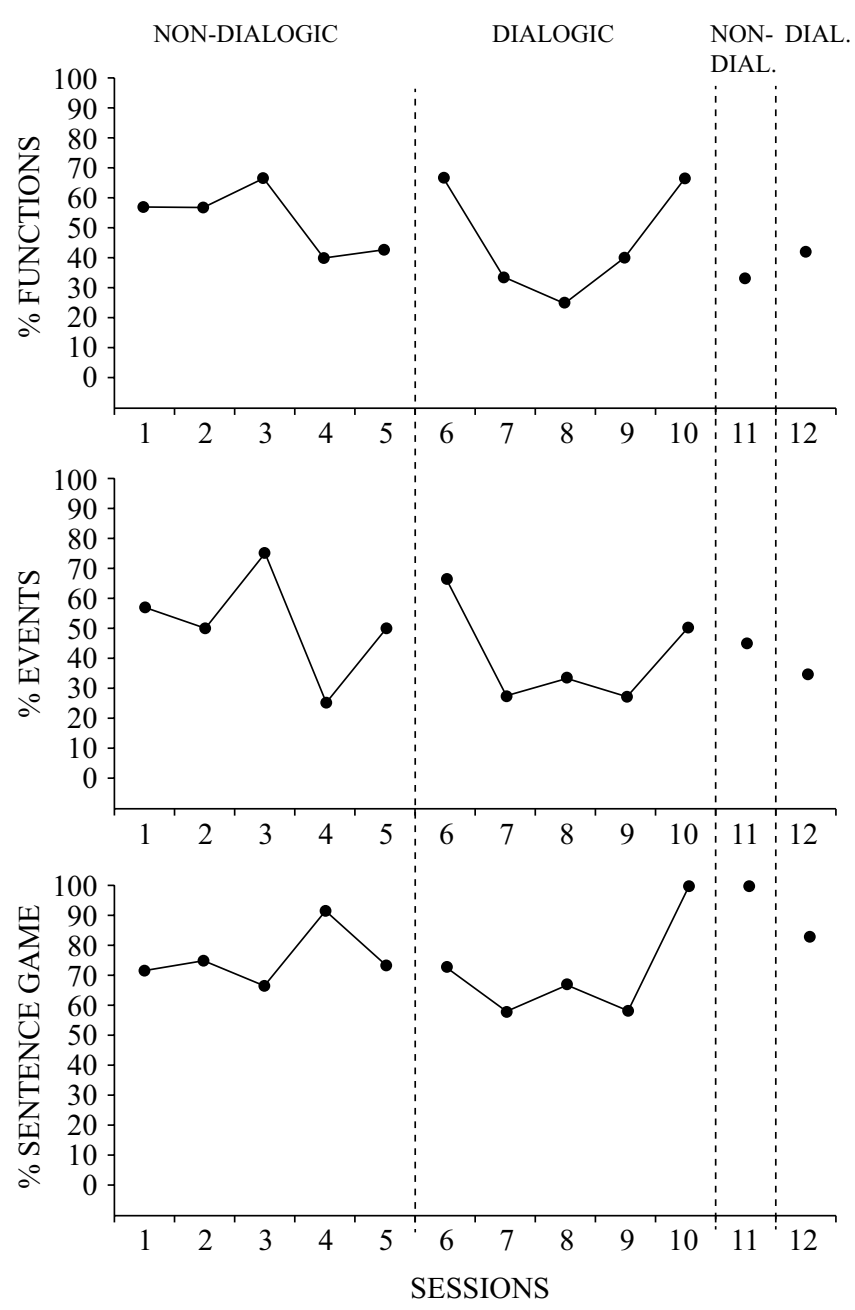

Figure 3. Percentage of functions achieved, events narrated and correct responses in the Sentence Game, per session, for participant P3.

due to variability of performance throughout the sessions, especially in Condition B.

Percentage of events for P3 varied between 25\% and $75 \%$ throughout the sessions, with no systematic relationship with the conditions or visible trends. Similarly, the number of correct responses in the Sentence Game ranged from 58\% to $100 \%$ throughout the sessions, with no evident relation between results and conditions. Like P2, P3's general performance, regardless of the condition, was higher in the Sentence Game than on the other tasks. 


\section{Discussion}

The main aim of this study was to investigate the effects of dialogic reading interventions, adapted to books in which text is predominant over illustrations, on the reading comprehension of children. We developed comprehension measures which allowed for repeated assessment with the same participant based on the notion of "functional units of the narrative", proposed by Roland Barthes. Such a functional analysis of text allows for an assessment of comprehension which is also functional, since correspondence is assessed by comparing functional features of the text and the child's talk, regardless of the exact words (form) used. For example, in a section from the story "My Mother is a Pirate" (French \& King, 2007), the Pirate Mom says she would love to see her son playing "kickball" (in the Portuguese translation, she says "chutebola", a nonexistent word in Portuguese). The Pirate Mom therefore invents a new word for futebol (football/soccer). Besides a humorous function, this section has the important function of indicating that the Pirate Mom is not acquainted with the conventions and customs of the contemporary world (the Pirate Ship in which they sail spends most of the time in another space-time dimension). One of the participants, while retelling this section, recalled laughingly that the Pirate Mom had called the soccer game "jogabola" ("playball", also a non-existent word in Portuguese). Despite having substituted "chutebola" with "jogabola", the functional unit of the narrative appeared clearly in the child's retelling. Thus, the analysis of narrative functions favored assessment focused on comprehension and not on literal reproduction.

Both P1 and P2 included more events and more narrative functions in the retelling tasks when exposed to dialogic reading and $\mathrm{P} 2$ also showed improved performance in the Sentence Game (P1 did not participate in this task). The prompts and feedback provided during dialogic reading offered many opportunities for the child to actively talk about important aspects of the story, and this may have favored performance on all three comprehension measures, compared with the non-dialogic condition.

Alternative explanations for the data of $\mathrm{P} 1$ and $\mathrm{P} 2$ could be specific characteristics of the day or the environment in which the experiment was carried out, or characteristics of the chapters used that may have facilitated or hindered retelling. However, such explanations seem unlikely if we consider that participants began participation at different times (there was a two week interval between the beginning of the experiment with P1 and with P2) and in different environments (in the clinic and in the school library). Furthermore, since changes in conditions (from A to B and from B to A) occurred in different sections of the novel for P1 and P2, attribution of differences in performance to specific chapters or sections also seems unlikely. Thus, the data obtained with $\mathrm{P} 1$ and $\mathrm{P} 2$ corroborate, using older children and with a more complex text, the data obtained in Brazil by Fontes and Cardoso-Martins (2004), who suggested that interactive or dialogic reading favors the comprehension of narratives. Unlike the aforementioned study, which compared dialogic reading with a condition without any intervention, this study compared dialogic reading with a control condition of non-dialogic shared reading.

The data from P3, in general, showed no systematic effects of dialogic reading on comprehension measures. Results cannot be attributed to ceiling or floor effects, since P3's performance remained between the two extremes throughout the sessions. It seems that dialogic reading, as implemented in this study, did not produce benefits for this participant's text comprehension. Further investigations are needed to assess how individual variables interact with dialogic reading and whether changes in the procedure could lead to improvements in P3's comprehension. Continuation of the experiment, however, was not possible due to practical limitations (preparation of text and prompts for twelve sessions and school holidays). It is possible that, for P3, the number of dialogic reading sessions was not sufficient to produce visible effects on comprehension. Since this is the first study which used a single-subject design to investigate the effects of dialogic reading, we have yet to establish the number of sessions necessary to oberve a clear effect of dialogic reading, which may be different from one individual to another. Ideally, sessions in Condition B would have been continued until levels of stability or clear trends were verified, before reversing to A.

Another hypothesis for the results concerns the genre used (children's novel) which was, simultaneously, a positive point and a limitation of the present study. On the one hand, the use of a children's novel offers greater ecological validity, compared to studies using texts specially tailored for experimental studies. Children's novels also have important advantages for studying comprehension, such as greater psychological density of the characters and more complex plots (in comparison with traditional oral tales, for example). From a methodological perspective, however, the text used had a sequence of events and involved the same characters from the beginning to the end. Such characteristics of the text may have interacted with the effects of dialogic reading on text comprehension. For example, if the prompts were important for comprehension, as suggested by the results of P1 and P2, the fact that P3's first sessions were non-dialogic may have had a carry-over effect on comprehension of important narrative functions in subsequent sessions. For example, the early chapters of the novel emphasize the ambivalence of Cecil's relationship with his pirate family members: he loves them, but he is embarrassed to introduce them to friends at school, because of what he sees as their eccentricity. Several sections highlight this narrative function at the beginning of the story, and comprehension of this narrative function is necessary to appreciate the meaning of events that occur later, such as when Cecil considers leaving school for good and becoming a pirate like everyone else in his family. Thus, it is important to replicate the present study with more control of this aspect, either by using different narratives, or by increasing the number of sessions and including more reversals in the design. 
The Sentence Game was included as an additional measure of comprehension and was also based on text functions. Regardless of conditions, performance on this task was superior than on retelling tasks, both for P2 and P3. Both children had been described by the pedagogic team as having difficulties with oral expression. The Free Retelling and Directed Retelling tasks, in which the child must reconstruct a coherent narrative, depend more heavily on verbal fluency and on familiarity with the narrative format Therefore, it was not surprising that the retelling tasks were more difficult for them than the Sentence Game, in which it is sufficient to recognize which sentences correspond to the story. Of course, correct answers may have happened by chance, since there are only two possible answers for each sentence (yes or no). However, it does not seem that P2's performance in the Sentence Game can be attributed to chance alone, since there was a systematic decrease in performance during non-dialogic conditions which showed the same pattern as the retelling tasks. (P1 was not exposed to this task and P3 showed no systematic effect of conditions on his performance in the Sentence Game).

Dialogic reading is an intervention package, and one limitation of this study is that it did not attempt to separate the effects of different components of dialogic reading. There is evidence, for example, that pauses during shared reading, of and by themselves, may be beneficial for text comprehension (Spinillo \& Hodges, 2012). As Gast (2010) recommends, if we wish to describe the independent variable and its effects with replicable precision, it is necessary to investigate which characteristics of an intervention package are crucial for specific results.

\section{Final Considerations}

The present study compared effects of dialogic and nondialogic reading on children's comprehension of a novel. For two of three participants, performance on comprehension tasks was higher when reading was done dialogically. This suggests that comprehension may be improved by including prompts during shared reading which encourage the child to actively engage in dialogue about important narrative functions. However, the results of the third participant showed no systematic effects of dialogic reading. In order to better understand this discrepancy, further studies should control for possible effects of narrative sequence, increase the number of sessions and reversals per participant, and test specific components of dialogic reading.

\section{References}

Aram, D., Fine, Y., \& Ziv, M. (2013). Enhancing parentchild shared book-reading interactions: Promoting references to the book's plot and socio-cognitive themes. Early Childhood Research Quarterly, 28(1), 111-122. doi:10.1016/j.ecresq.2012.03.005
Barthes, R. (2009). Introdução à análise estrutural da narrativa. In R. Barthes e cols. (Eds.). Análise Estrutural da Narrativa (6th ed.) (pp.19-62) (M. B. Pinto, Trad.). São Paulo: Vozes [Original published in 1966].

Cabell, S. Q., Justice, L. M., Konold, T. R., \& McGinty, A. S. (2011). Profiles of emergent literacy skills among preschool children who are at risk for academic difficulties. Early Childhood Research Quarterly, 26(1), 1-14. doi:10.1016/j.ecresq.2010.05.003

Camelo, M. L., \& Souza, C. B. A. (2009). Leitura dialógica, consciência fonológica e o desenvolvimento de repertórios verbais. In R. C. Wielenska (Org.), Sobre Comportamento e Cognição, (Vol. 24, pp. 159-168). Santo André: ESETec.

Flynn, K. S. (2011). Developing children's oral language skills through dialogic reading: guidelines for implementation. Teaching exceptional children, 44(2), 8-16.

Fontes, M. J. O., \& Cardoso-Martins, C. (2004). Efeitos da leitura de histórias no desenvolvimento da linguagem de crianças de nível sócio-econômico baixo. Psicologia: Reflexão e Crítica, 17(1), 83-94. doi:10.1590/S0102-79722004000100011

French, J., \& King, S. M. (2007). Minha mãe é uma pirata. São Paulo: Fundamento.

Gast, D. L. (2010). Applied research in education and behavioral sciences. In D. L. Gast, \& J. Ledford (Orgs.), Single-subject research methodology in behavioral sciences [Kindle Version DX]. Retrieved from http://www. amazon.com/Single-Subject-Research-MethodologyBehavioral-Sciences-ebook/dp/B002RGMKF

Johnston, J. M., \& Pennypacker, H. S. (2008). Strategies and tactics of behavioral research (3rd ed.). Psychology Press. New York: Routledge.

Lever, R., \& Sénéchal, M. (2011). Discussing stories: how a dialogic reading intervention improves kindergartners' oral narrative construction. Journal of Experimental Child Psychology, 108(1), 1-24. doi:10.1016/j.jecp.2010.07.002

Lonigan, C. J. Purpura, D. J., Wilson, S. B., Walker, P. M., \& Clancy-Menchetti, J. (2013). Evaluating the components of an emergent literacy intervention for preschool children at risk for reading difficulties. Journal of Experimental Child Psychology, 114(1), 111-130. doi:10.1016/j. jecp.2012.08.010

Morrow, L. (2009). Literacy development in the early years. New York, NY: Pearson.

Rodrigues, M. C., Ribeiro, N. N., \& Cunha, P. C. (2012). Leitura mediada com enfoque sociocognitivo: avaliação de uma pesquisa-intervenção. Paidéia (Ribeirão Preto), 22(53), 393-402. doi:10.1590/1982-43272253201311

Spinillo, A. G., \& Hodges, L. V. S. D. (2012). Error analysis and reading comprehension: Comparisons between different reading situations. Psicologia: Teoria e Pesquisa, 28(4),381-388. doi:10.1590/S0102-37722012000400006 
Valdez-Menchaca, M. C., \& Whitehurst, G. J. (1992). Accelerating language development through picture book reading: A systematic extension to Mexican day care. Developmental Psychology, 28(6), 1106-1114. doi:10.1037/0012-1649.28.6.1106

Vally, Z. (2012). Dialogic reading and child language growth: combating developmental risk in South Africa. South African Journal of Psychology, 42(4), 617-627. doi:10.1177/008124631204200415

Whitehurst, G. J. Falco, F. L., Lonigan, C. J., Fischel, J. E., DeBaryshe, B. D., Valdez-Menchaca, M. C., \& Caulfield, M. (1988). Accelerating language development through picture book reading. Developmental Pyschology, 24(4), 552-559. doi:10.1037/0012-1649.24.4.552

Whitehurst, G. J., \& Lonigan, C. J. (1998). Child development and emergent literacy. Child Development, 69(3), 848-872.

Whitehurst, G. J., Zevenbergen, A. A., Crone, D. A., Schultz, M. D., Velting, O. N., \& Fischel, J. E. (1999). Outcomes of an emergent literacy intervention from Head Start through second grade. Journal of Educational Psychology, 91(2), 261-272. doi:10.1037/0022-0663.91.2.261

Zevenbergen, A. A., Whitehurst, G. J., \& Zevenbergen, J. A. (2003). Effects of shared-reading intervention on the inclusion of evaluative devices in narratives of children from low-income families. Journal of Applied Developmental Psychology, 24(1), 1-15. doi:10.1016/S0193-3973(03)00021-2

Eileen Pfeiffer Flores is an Associate Professor of the Universidade de Brasília.

Laís Fernandes Pires is a Psychology undergraduate student of the Universidade de Brasília.

Carlos Barbosa Alves de Souza is an Associate Professor of the Universidade Federal do Pará.

Received: Apr. 18, 2013

1st Revision: Mar. 6, 2014

Approved: Mar. 15, 2014

How to cite this article:

Flores, E. P., Pires, L. F., \& Souza, C. B. A. (2014). Dialogic reading of a novel for children: Effects on text comprehension. Paidéia (Ribeirão Preto), 24(58), 243-251. doi: 10.1590/1982-43272458201412 


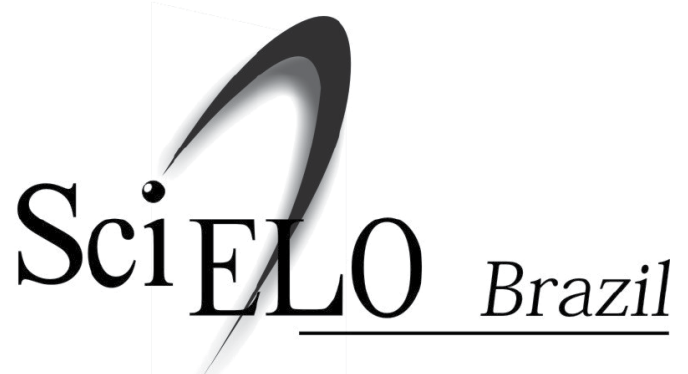
Paidéia (Ribeirão Preto) is a four-monthly publication available in full-text in the Scientific Electronic Library Online - SciELO.

The SciELO interface provides easy access to the tables of content and to the full-text articles.

The SciELO interface also provides the retrieval of articles by the author's name, the words from title, abstract and descriptors, in addition to providing bibliometric indicators and consultation indicators.

The articles are enriched with connections to the LILACS, MEDLINE and PubMed databases.

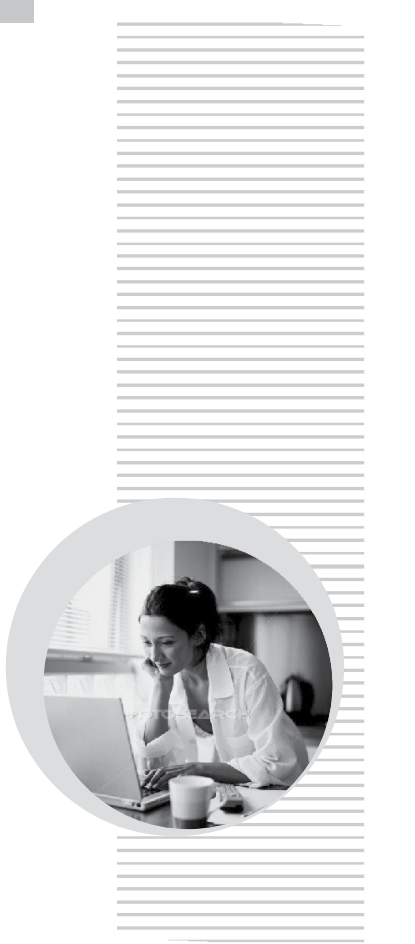

Paidéia (Ribeirão Preto) is a part of SciELO Brazil:

\section{www.scielo.br/paideia}

The SciELO interface provides access to a network of SciELO websites, gathering the major scientific journals of Latin America, Caribbean, Spain, Portugal and South Africa:

\section{www.scielo.org}

The electronic library is a project developed by the São Paulo Research Foundation (FAPESP), in partnership with the Latin American and Caribbean Center on Health Sciences Information (BIREME) and the National Council for Scientific and Technological Development (CNPq). 